\title{
USING EXPERIMENTAL EX VIVO MODELS TO DEVELOP COVID-19 PATHOGENETIC THERAPY AND COMPLICATIONS PREVENTION AGENTS
}

Laptev DS $\bowtie$, Petunov SG, Nechaykina OV, Bobkov DV, Radilov AS

Research Institute of Hygiene, Occupational Pathology and Human Ecology FMBA, Leningrad region

COVID-19 is a disease characterized by damage to the lower respiratory tract, development of the acute respiratory distress syndrome, in severe cases — multiple organ failure, including acute heart failure and cardiomyopathy. This study aimed to evaluate the effectiveness of the developed COVID-19 pathogenetic therapy and complications prevention agents using the ex vivo isolated lung and heart models. Isolated organs of white rats were used for the research; the dynamics of functional indicators were analyzed. An amino acid-peptide complex (APC) from a thermally treated milk protein hydrolyzate was used as the experimental COVID-19 pathogenetic therapy and complications prevention agent. Introduction of the APC to the isolated cardiopulmonary complex perfusate slowed down development of pulmonary edema in the experimental group; the organ's weight was 1.5 times less than in the control group ( $p=0.0158$ ). We have also registered an airway resistance downtrend. APC supported contractile activity of the isolated myocardium suffering ischemia-reperfusion: the growth of the left ventricular end diastolic pressure was 34\% smaller than that registered in the control group $(p<0.05)$. The APC's cardioprotective effect relies on the endothelium-dependent mechanisms. The ex vivo method is highly informative. It allows assessing reactivity of the isolated organs exposed to biologically active substances and determining the possibilities of compensating for functional changes.

Keywords: isolated heart, ischemia, isolated lung, pulmonary edema, COVID-19

Author contribution: Laptev DS - experimental part, information collection, data processing; Petunov SG - data processing and interpretation, general guidance; Nechaykina OV — experimental part, information collection; Bobkov DV — data processing; Radilov AS — data processing and interpretation.

Compliance with ethical standards: all work with animals was carried out in conformity to the provisions of the European Convention for the Protection of Vertebrate Animals used for Experimental and other Scientific Purposes.

Correspondence should be addressed: Denis S. Laptev

st. Kapitolovo, gor. pos. Kuzmolovsky, 93, Vsevolozhsky rajon, 188663; lapden@mail.ru

Received: 15.09.2020 Accepted: 25.11.2020 Published online: 12.12.2020

DOI: $10.47183 /$ mes.2020.020

\section{ИСПОЛЬЗОВАНИЕ ЭКСПЕРИМЕНТАЛЬНЫХ МОДЕЛЕЙ ЕХ VIVО ДЛЯ РАЗРАБОТКИ СРЕДСТВ ПАТОГЕНЕТИЧЕСКОЙ ТЕРАПИИ И ПРОФИЛАКТИКИ ОСЛОЖНЕНИЙ COVID-19}

\section{Д. С. Лаптев $\bowtie$, С. Г. Петунов, О. В. Нечайкина, Д. В. Бобков, А. С. Радилов}

Научно-исследовательский институт гигиены, профпатологии и экологии человека Федерального медико-биологического агентства, Ленинградская область, Россия

COVID-19 - заболевание, характеризующееся поражением нижних дыхательных путей, формированием острого респираторного дистресс-синдрома, в тяжелых случаях - развитием полиорганной недостаточности, в том числе острой сердечной недостаточности и формированием кардиомиопатии Целью работы было оценить эффективность разрабатываемых средств патогенетической терапии и профилактики осложнений COVID-19 с использованием моделей изолированных легких и сердца ех vivo. Исследования проводили на изолированных органах белых крыс с анализом динамики функциональных показателей. В качестве средства экспериментальной патогенетической терапии и профилактики осложнений COVID-19 использовали аминокислотно-пептидный комплекс (АПК) из термически обработанного гидролизата молочного белка. Добавление АПК в перфузат изолированного сердечно-легочного комплекса способствовало снижению скорости формирования отека легких в опытной группе, при этом масса органа была в 1,5 раза меньше, чем в контрольной группе ( $p$ = 0,0158). Показана тенденция к снижению сопротивления дыхательных путей. Применение АПК способствовало поддержанию сократительной активности изолированного миокарда в условиях ишемии-реперфузии: увеличение конечного диастолического давления было на 34\% меньше по сравнению с контролем ( $<$ < 0,05). Кардиопротекторное действие АПК обусловлено эндотелийзависимыми механизмами. Метод ех vivo обладает высокой информативностью, позволяет провести оценку реактивности изолированных органов при действии биологически активных веществ и определить возможности компенсации функциональных изменений.

Ключевые слова: изолированное сердце, ишемия, изолированное легкое, отек легких, COVID-19

Вклад авторов: Д. С. Лаптев - экспериментальная часть, сбор информации, обработка данных; С. Г. Петунов - обработка и интерпретация данных, общее руководство; О. В. Нечайкина — экспериментальная часть, сбор информации; Д. В. Бобков - обработка данных; А. С. Радилов — обработка и интерпретация данных

Соблюдение этических стандартов: все работы с животными выполняли с соблюдением правил биоэтики, утвержденных Европейской конвенцией о защите позвоночных животных, используемых для экспериментальных и других целей.

$\bigotimes$ Для корреспонденции: Денис Сергеевич Лаптев

Ст. Капитолово, корп. 93, г. п. Кузьмоловский, Всеволожский район, 188663; lapden@mail.ru

Статья получена: 15.09.2020 Статья принята к печати: 25.11.2020 Опубликована онлайн: 12.12.2020

DOI: $10.47183 /$ mes.2020.020

SARS-CoV-2 belongs to the group of highly pathogenic coronaviruses that cause a clinical syndrome known as the novel coronavirus infection (COVID-19). In severe cases, COVID-19 is a systemic disease associated with lower respiratory tract damage, development of pneumonia, acute respiratory distress syndrome (ARDS), cytokine storm and growing levels of the heart damage biomarkers [1].
Mainly, the infection caused by SARS-CoV-2 manifests in the form of respiratory failure, which is the result of SARSCoV-2 penetrating into target cells that have angiotensinconverting enzyme 2 (ACE2) receptors. In particular, this enzyme is expressed on alveolar type II pneumocytes (AT2), in enterocytes of the small intestine's epithelium, in the vascular endothelium and in cardiomyocytes. In the lungs, SARS-CoV-2 
causes desquamation of type II and type I pneumocytes, which translates into alveolar dysfunction, lower surfactant levels, accumulation of liquid exudate in the alveolar space and pulmonary edema, which dramatically reduces the effectiveness of external respiration. This stage is characterized by moderate constitutional symptoms and determines the initial response of innate immunity [2].

From the point of view of morphological changes, SARSCoV-2 patients may have edema with pleural effusion, focal hemorrhages and mucopurulent secretion in the airways. A distinctive histological feature observed at later stages is the diffuse lung lesion with fibrin exudation in the alveolar spaces and septal and alveolar fibrosis [3, 4]. Even if the viral load decreases, stronger inflammatory response leads to systemic inflammation [1], which is characterized by multiple organ failure and the increasing number of key inflammation markers.

The development of myocarditis associated with COVID-19 and going without signs of direct viral infiltration indicates that the heart is one of the targets of systemic inflammation [5], with the biomarkers of heart damage and electrocardiographic abnormalities in accord with the elevated levels of inflammatory markers [6, 7].

Either on its own or in combination with respiratory failure, heart damage and failure were the cause of death associated with COVID-19 in 40\% of cases registered in one of the cohorts traced in Wuhan, PRC. The risk of death associated with acute myocardial injury was more significant than such factors as age, diabetes mellitus, chronic lung disease or previous cardiovascular disease $[6,8,9]$. Thus, damage to the heart is both a predominant type of COVID-19 complication and, as it seems, one of the complications to be predicted.

The mechanisms behind damage to the heart induced by SARS-CoV-2 remain virtually unstudied, however, it is likely they include both direct infection of the myocardium and the consequences of respiratory failure, hypoxemia, and systemic inflammatory response. Signaling pathways associated with ACE2, which are highly expressed in the heart, may also play a role in myocardial damage [9].

The significant severity of COVID-19 clinical manifestations and consequences thereof make it a priority to develop drugs to effectively prevent the development of severe conditions that translate, first of all, into acute damage to lungs and heart. Preclinical evaluation of the effectiveness of pharmacological agents requires use of experimental models that allow assessing the dynamics of parameters of the target organs' functional activity, such assessment adequate to the tasks set. Ex vivo experiments with isolated organs are highly informative: they allow objective registration of the organs' activity parameters.

A

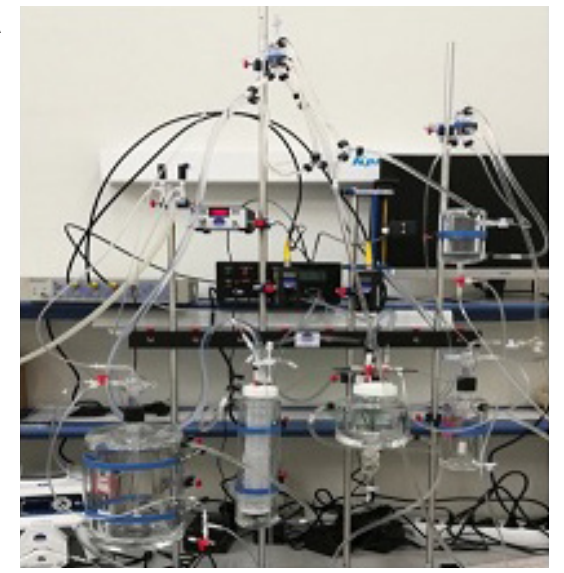

The purpose of this work was to demonstrate the possibility of using isolated organs - heart and lungs - as models in preclinical studies of the effectiveness of developed COVID-19 pathogenetic therapy and complications prevention agents.

\section{METHODS}

The subjects were isolated lungs and hearts of white male Wistar rats weighing 280-360 g, obtained from the Rappolovo laboratory animal nursery (Leningrad region). The experimental animals were kept in conditions conforming to the Sanitary Rules for the Design, Equipment and Maintenance of Experimental Biological Clinics (vivariums). For research, we used healthy sexually mature animals quarantined for at least 10-14 days. The controlled microclimate parameters in the rooms where the animals were kept were temperature of $20 \pm 1{ }^{\circ} \mathrm{C}$, relative air humidity of $60 \pm 5 \%$. We have also controlled the quality of the bedding material. The animals received standard pellet feed. The lighting regime for the rooms containing experimental animals was $12 \mathrm{~h}$ of day and $12 \mathrm{~h}$ of night.

\section{Isolated lung model}

In addition to the gas exchange function, the model allows assessing the contribution of external respiration to metabolism of biologically active substances and the associated microcirculation in the pulmonary circulation. This model can be used to study pathogenesis of the bronchopulmonary diseases, including development of the pulmonary edema, as well as to assess the effectiveness of symptomatic and pathogenetic therapeutic agents designed for the respiratory system.

The experimental animals were anesthetized with a $20 \%$ urethane solution injected intraperitoneally and subcutaneously, $1.2 \mathrm{~g}$ per a $\mathrm{kg}$ of animal body weight. After a midline laparotomy, we injected heparin into the inferior vena cava to prevent thrombogenesis. Then we cannulated the trachea at the thyroid gland level and put the animal on a mechanical ventilator (respiratory rate $-50 \mathrm{~min}^{-1}$, tidal volume $-1.7 \mathrm{ml}$, minute respiration volume $-85 \mathrm{ml} / \mathrm{min}$ )

After opening the thoracic cavity, we cannulated the pulmonary artery and connected to the peristaltic pump of the experimental rig; thus, we simulated pulmonary circulation. After removal of the heart-lung complex from the chest, we weighed it and placed it in Isolated Lung System (Radnoti; Ireland) chamber (Fig. 1), where the temperature and humidity were kept optimal for the object studied.

At the end of the first 30 min (stabilization period), the tidal volume was gradually, within 15 minutes, increased from 1.7

B

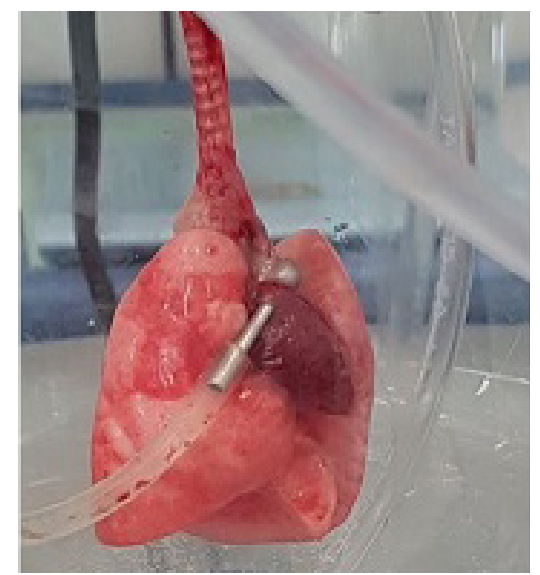

Fig. 1. Isolated lung system. A. General view of the installation. B. Heart-lungs complex 

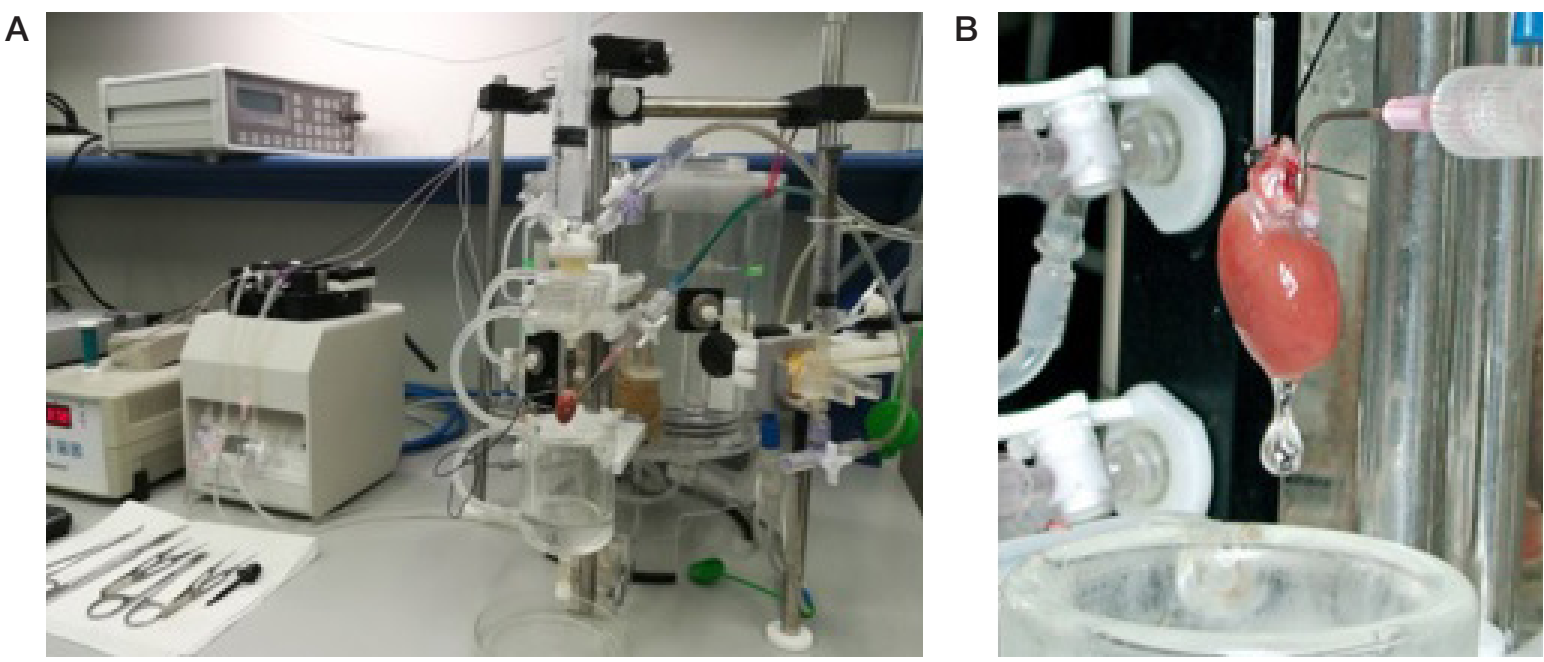

Fig. 2. Installation of an isolated heart according to Langendorff. A. General view. B. Cannulated heart

to $2.3 \mathrm{ml}$. For artificial circulation in the pulmonary circuit, we used Krebs-Henseleit solution of the following composition (in mM): $\mathrm{NaCl}$ (118.99); $\mathrm{KCl}$ (4.69); $\mathrm{NaHCO}_{3}$ (25.00); $\mathrm{KH}_{2} \mathrm{PO}_{4}$ (1.18); $\mathrm{MgSO}_{4} \times 7 \mathrm{H}_{2} \mathrm{O}(1.17) ; \mathrm{CaCl}_{2} \times 2 \mathrm{H}_{2} \mathrm{O}(2.5) ; \operatorname{EDTA}(0.03) ;$ glucose (5.5). The prepared solution was aerated with a gas mixture containing $5 \% \mathrm{CO}_{2}$ and $95 \% \mathrm{O}_{2}$. In the experimental group, we added the biologically active component to the carbogen-enriched Krebs-Henseleit solution at a concentration of $1 \times 10^{-6} \mathrm{M}$. The flow rate of the perfusate reached $1.5 \mathrm{ml} / \mathrm{min}$. The duration of the perfusion was $1.5 \mathrm{~h}$; at the end of the experiment, the heart-lung complex was weighed again. In the given experimental conditions, development of the edema is caused by a drop in the perfusate's oncotic pressure: liquid from pulmonary circulation diffuses into the interstitium of the alveoli.

The registered parameters were perfusion pressure in the pulmonary circulation, lung mass and intratracheal pressure.

\section{Isolated heart model}

For the isolated heart model experiment, we euthanized the animals by cervical dislocation. Bilateral transabdominal thoracotomy allowed wide access to the cavity. The heart, once exposed, was taken by the base with thumb and forefinger of the left hand, carefully pulled ventrally and downward, then the great vessels were cut with scissors. Immediately after the heart was removed from the chest cavity, it was placed in Krebs-Henseleit saline solution of the following composition (in $\mathrm{mM}$ ): $\mathrm{NaCl}$ (118.99); $\mathrm{KCl}$ (4.69); $\mathrm{NaHCO}_{3}$ (25); $\mathrm{KH}_{2} \mathrm{PO}_{4}$ (1.18); $\mathrm{MgSO}_{4} \times 7 \mathrm{H}_{2} \mathrm{O}$ (1.17); $\mathrm{CaCl}_{2} \times 2 \mathrm{H}_{2} \mathrm{O}$ (2.5); EDTA (0.03); $\mathrm{C}_{6} \mathrm{H}_{12} \mathrm{O}_{6}$ (5.5). The aorta was fixed to the cannula of the Langendorff System perfusion rig (Panlab; Spain) with a crocodile clamp and then with ligatures (Fig. 2).

The heart was perfused through a cannula in the aorta, with the perfusate retrogradely delivered to the left ventricle. The perfusate was Krebs-Henseleit solution warmed to $37^{\circ} \mathrm{C}$. To bring its $\mathrm{pH}$ to the physiological level (7.4) and to ensure adequate oxygenation of the heart, the solution was Table 1. Heart-lungs complex weight $(\mathrm{M} \pm \mathrm{SD}), n=7$ continuously saturated with carbogen. The feeding rate of the perfusate was $10 \mathrm{ml}$ per minute per $1 \mathrm{~g}$ of wet weight of the heart. The perfusion adequacy control value was pressure (not less than $50 \mathrm{~mm} \mathrm{Hg}$ ) in the "pump-aortic cannula" circuit.

We used a catheter with a polyethylene balloon to measure pressure in the left ventricle. The parameters of cardiac contractile activity were recorded with the PowerLab Data acquisition system 8/30 (ADInstruments; USA) and subsequently processed in the LabChartProUpgrade 7.0 software (ADInstruments; USA).

The most significant recorded indicators were pulse pressure $(\mathrm{PP})$, heart rate $(\mathrm{HR})$, end-diastolic pressure (EDP), which describes the ability of the myocardium to support cardiac output and create the necessary pressure in the vascular system. Additionally, we calculated the first time derivative of pressure $(+\mathrm{dP} / \mathrm{dt}$ and $-\mathrm{dP} / \mathrm{dt})$, which reflects the rate of pressure change in the left ventricle. The dynamics of $+\mathrm{dP} / \mathrm{dt}$ and $-\mathrm{dP} / \mathrm{dt}$ reflects functional state of the ventricles: energy metabolism, permeability of cell membrane ion channels and sarcoplasmic reticulum.

After the stabilization period (30 minutes) was over, we added the active component to the perfusate at the concentration of $1 \times 10^{-6} \mathrm{M}$. The exposure time was 10 minutes. It was determined by the rate of development of vascular reactions to the vasoactive substance.

To assess the resistance of the isolated myocardium to ischemia/reperfusion, we induced total ischemia by stopping the perfusion for 30 minutes at $37{ }^{\circ} \mathrm{C}$, and then started reperfusion, which lasted for 30 minutes.

Analyzing the results, we assessed the dynamics of functional indicators of isolated heart and lungs, compared them to the background and control values. Statistical processing was performed using GraphPad Prism 5.04 (GraphPad Software Inc; USA). To compare the results with normal distribution of the data, we applied Student's $t$ test; when the distribution was different from normal, we applied the paired samples Wilcoxon test; Mann-Whitney $U$ test was

\begin{tabular}{|c|c|c|c|}
\hline \multirow{2}{*}{ Experimental series } & \multicolumn{2}{|c|}{ Heart-lungs complex weight, } & \multirow{2}{*}{ Weight gain, \% } \\
\cline { 2 - 4 } & at the beginning of the experiment & at the end of the experiment & $300.7 \pm 66.4$ \\
\hline Control & $4.9 \pm 0.5$ & $14.9 \pm 3.9$ & $205.7 \pm 42.8^{\star}$ \\
\hline Experimental $\left(1 \pm 10^{-6} \mathrm{M}\right)$ & $4.9 \pm 0.7$ & $10.1 \pm 2.3$ & \\
\hline
\end{tabular}

Note: * - statistically significant differences with the control series of experiments. 


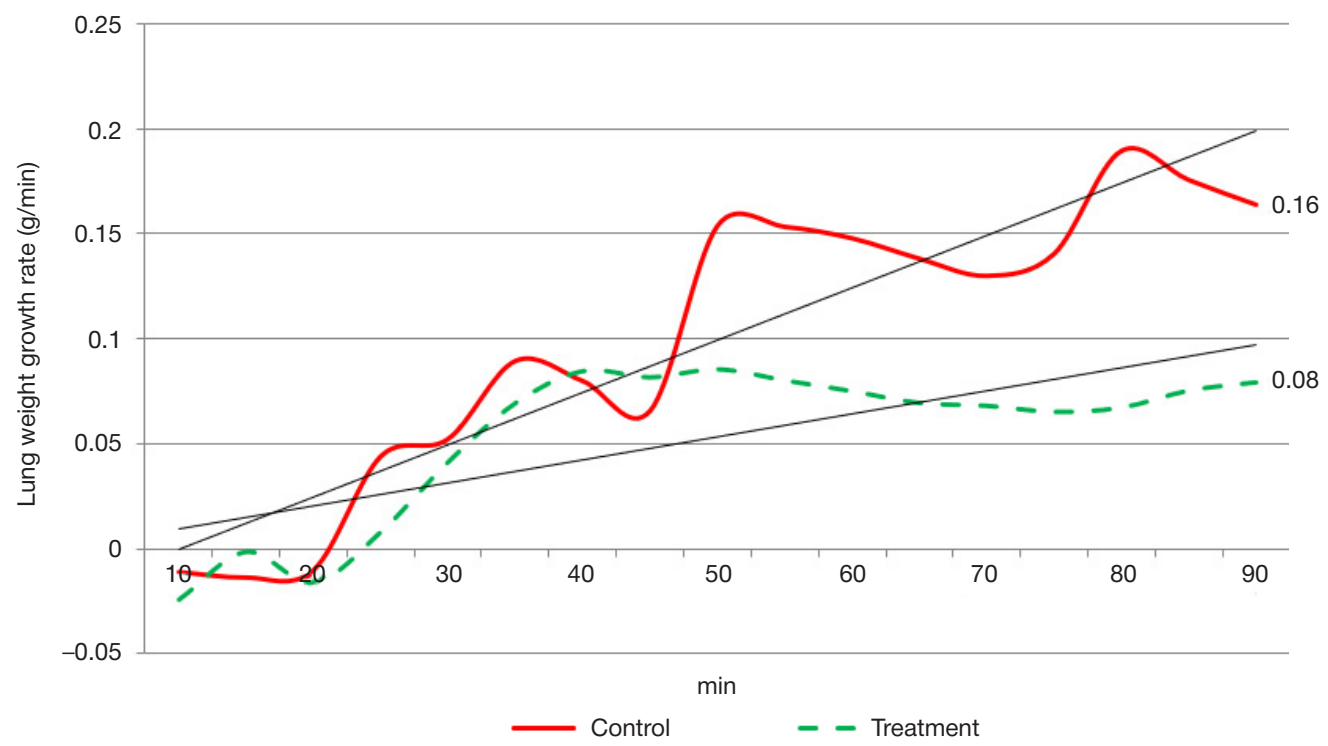

Fig. 3. Lung weight growth rate, treatment and control groups

used to assess intergroup differences. The differences were considered significant at $p \leq 0.05$.

The selected experimental COVID-19 pathogenetic therapy and complications prevention agent was APC (FSUE "NII GPECH" FMBA; Russia) made from thermally treated hydrolyzate of milk protein and enriched with proline and alanine, including linear and cyclic peptides. The active components of the complex improve tissue blood supply by stimulating endothelial nitric oxide synthase. This effect shapes the APC's cardioprotective properties [10]. There seems to be promise in using APC as a stroke prevention agent, part of the ischemic brain damage therapy, as well as an agent alleviating pulmonary edema by decreasing vascular resistance in the pulmonary circulation [7].

\section{RESULTS}

The study showed that 1.5 hours of perfusion increased the weight of the heart-lungs complex in both groups, but in the experimental group, this increase was significantly smaller $(p<0.05)$ than in the control group (Table 1).

Starting from the $45-50^{\text {th }}$ minute of exposure, the heartlungs complex weight growth accelerates significantly in the control group, whereas in the experimental group its rate remains the same (Fig. 3).

As for the perfusion pressure in the pulmonary circulation vessels, it did not differ significantly between groups (Fig. 4), which suggests that APC has little effect on their resistance.

Experimentally, we identified that the resistance of airways of the isolated lungs tends to decrease when the perfusate is supplemented with APC components, which may indicate that pulmonary edema is less severe in the experimental group (Fig. 5).

The heart model isolated in the Langendorff system allowed establishing that the active components of the APC at the concentration of $1 \times 10^{-6} \mathrm{M}$, which corresponds to the $50 \mathrm{mg} / \mathrm{kg}$ dose when administered intragastrically, do not significantly affect functional parameters of an intact rat heart but promote an end-diastolic pressure drop $(p<0.05)$ under ischemia-reperfusion (Fig. 6) and support the rate at which the myocardium contracts and relaxes during the cardiac cycle (Table 2).

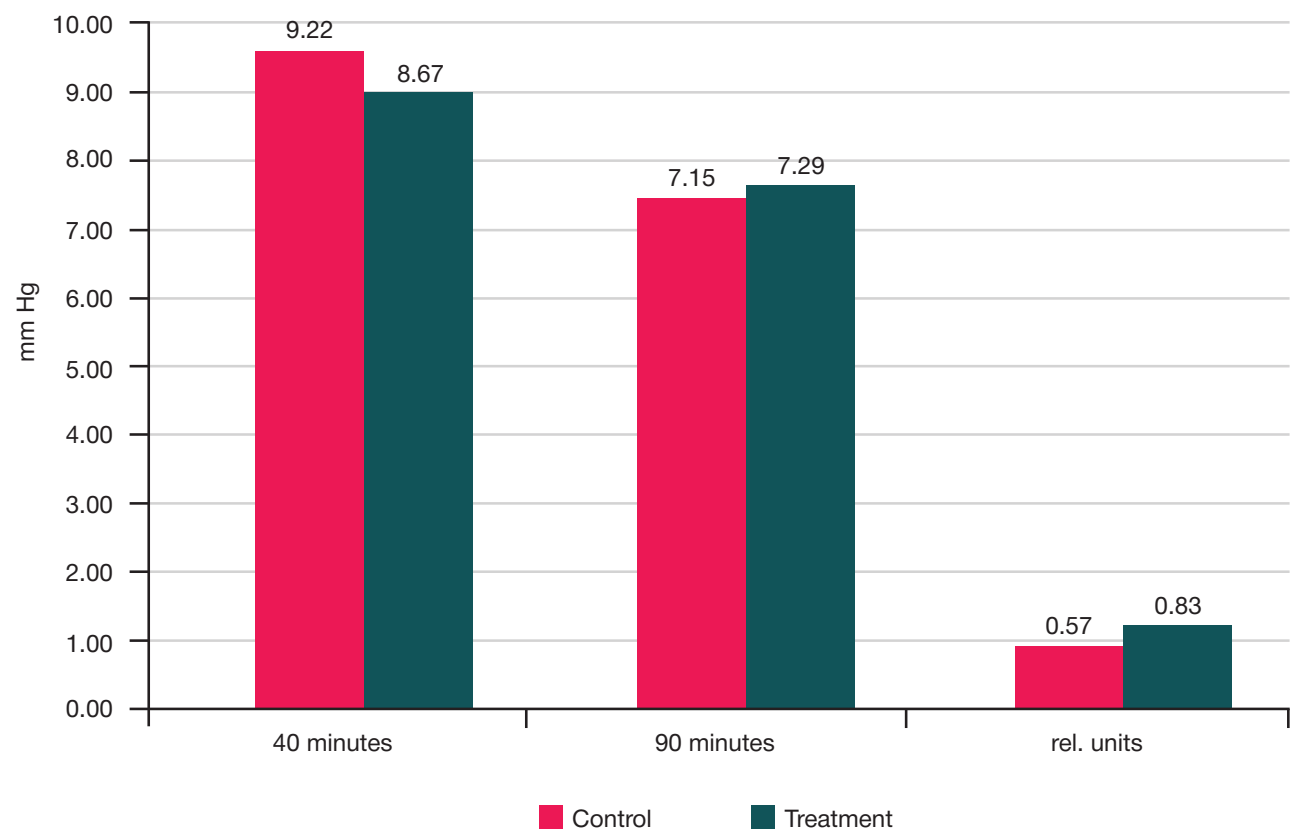

Fig. 4. Isolated lung perfusion pressure dynamics. The ratio of initial and final perfusion pressure is given in relative units 


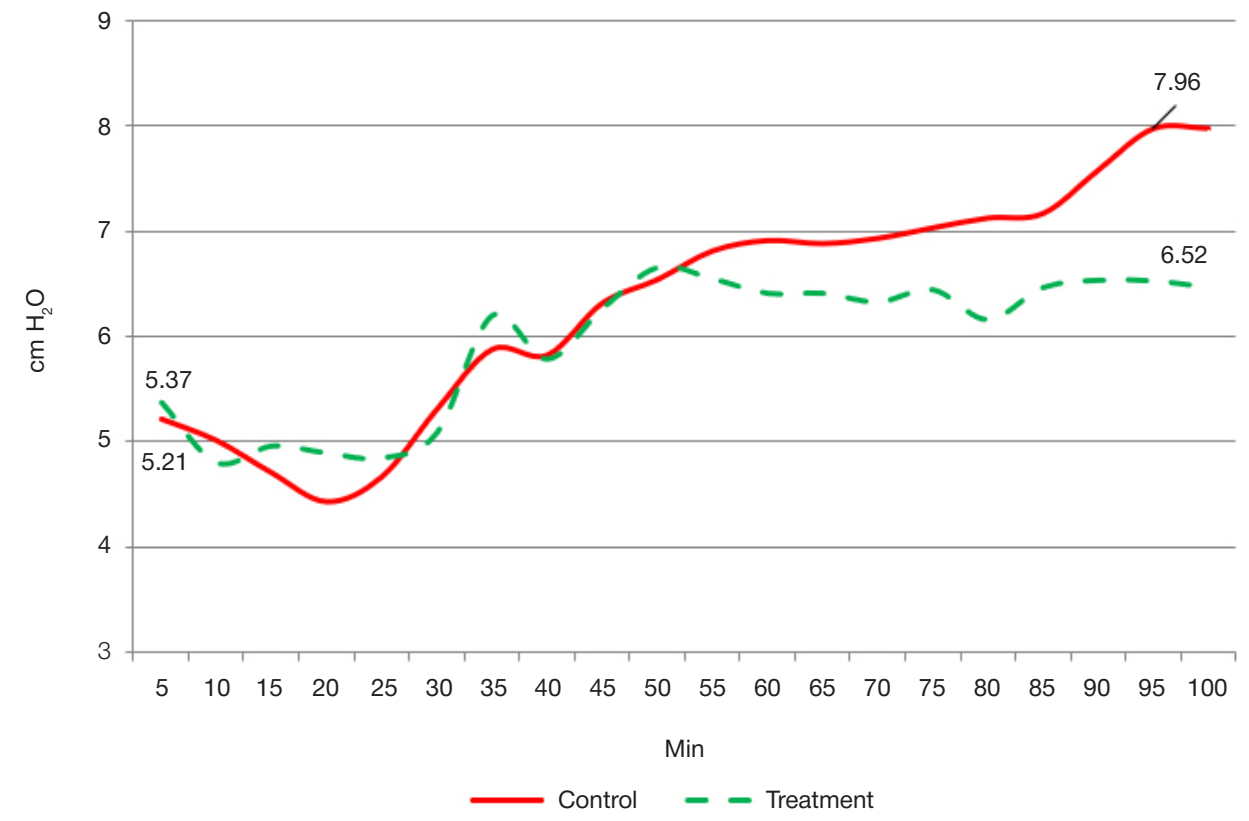

Fig. 5. Isolated lung intratracheal pressure dynamics

Administration of the nitric oxide synthase blocker L-NAME led to a significant end-diastolic pressure growth, which signals of poorer myocardial relaxation and diastolic filling. These changes were also accompanied by a decrease in pulse pressure, which jointly contributed to deterioration of the heart's pumping function.

\section{DISCUSSION}

Active components of the studied APC effectively regulate cellular energy metabolism, promote preferential utilization of the more energy-intensive long-chain fatty acids, which supports energy homeostasis, especially in conditions of energy deficiency. Regulation of the transcriptional activity of PPAR $\delta$ boosts body's endurance, improves blood supply to the tissues and accelerates lipolysis [11]. The APC promotes glucose uptake by direct translocation of GLUT transporters onto plasma membrane, which makes it a promising agent for mitochondrial dysfunction cases [12]. Endothelial nitric oxide synthase is one of the APC's targets, which shapes its cardioprotective properties and substantiates the use of APC as a heart failure prevention agent [13]. In addition, APC helps inhibit secretion of the pro-inflammatory cytokines and has a moderate antimicrobial effect.

According to the data revealed by the study, administration of APC helps maintain the lung mass stable through the

EDP

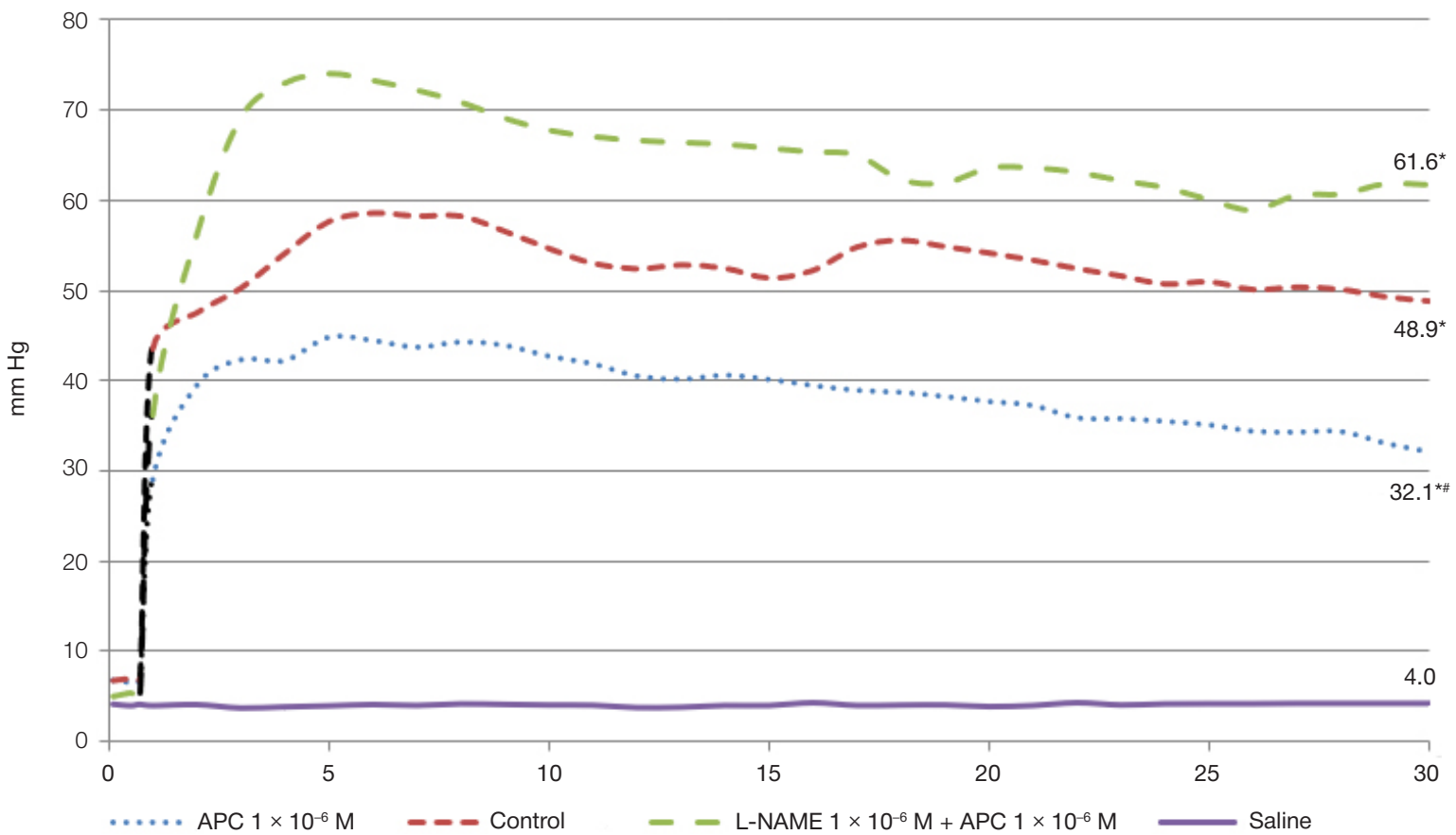

Fig. 6. End diastolic pressure dynamics, isolated heart during reperfusion after 30 minutes of total normothermic $\left(37^{\circ} \mathrm{C}\right)$ ischemia. APC administered. ${ }^{\star}$ - the differences are statistically significant in comparison with the intact organ; \# — the differences are statistically significant in comparison with the "reperfusion (control)" group $(p<0.05)$ 
Table 2. Indicators of myocardial contractility with APC administered. The data provided are relative to the background, in \% (M \pm SE); for the EDP the data is absolute, $n=7$

\begin{tabular}{|l|c|c|c|c|c|}
\hline \multicolumn{1}{|c|}{ Perfusate } & Heart rate & $\mathrm{PP}$ & $+\mathrm{dP} / \mathrm{dt}$ & $-\mathrm{dP} / \mathrm{dt}$ & $\mathrm{EDP}(\mathrm{mm} \mathrm{Hg})$ \\
\hline Saline, $30 \mathrm{~min}$ & $91.6 \pm 3.4$ & $101.5 \pm 3.4$ & $103.1 \pm 2.1$ & $96.7 \pm 3.1$ & $4.0 \pm 1.6$ \\
\hline APC1 $\times 10^{-6} \mathrm{M}$ & $101.0 \pm 1.8$ & $99.0 \pm 2.1$ & $99.0 \pm 0.9$ & $99.5 \pm 0.7$ & $3.9 \pm 2.4$ \\
\hline Reperfusion, control & $91.1 \pm 7.1$ & $53.7 \pm 7.6^{*}$ & $58.7 \pm 7.3^{*}$ & $70.3 \pm 7.7^{*}$ & $48.9 \pm 4.9^{*}$ \\
\hline Reperfusion APC $1 \times 10^{-6} \mathrm{M}$ & $95.0 \pm 4.5$ & $64.0 \pm 12.5^{*}$ & $80.9 \pm 10.6^{*}$ & $95.6 \pm 9.2^{*}$ & $32.1 \pm 5.7^{* *}$ \\
\hline Reperfusion L-NAME $1 \times 10^{-6} \mathrm{M}+\mathrm{APC} 1 \times 10^{-6} \mathrm{M}$ & $95.5 \pm 1.9$ & $41.2 \pm 11.5^{*}$ & $54.9 \pm 9.5^{*}$ & $73.2 \pm 13.9^{*}$ & $61.6 \pm 6.7^{*}$ \\
\hline
\end{tabular}

Note: * — the differences are statistically significant in comparison with the intact organ; \# — the differences are statistically significant in comparison with the "reperfusion (control)" group $(p<0.05)$

experiment, possibly due to the decreasing permeability of the blood-air barrier. As a result of 1.5 hours of perfusion, the weight of the isolated heart-lungs complex increased in both groups, but in the experimental group this increase was 1.5 times smaller than in the control group $(p=0.0158)$. The difference, detectable from the $40^{\text {th }}$ minute of perfusion, is obviously caused by the greater excursion of the lungs triggered by the increasing tidal volume (up to the recommended values, as per the methodology) [14]. This growth of the lung volume can raise pressure gradient between the perfused vessels of pulmonary circulation and the alveolar space, which facilitates release of fluid into the interstitium of the alveoli and promotes edema development [15].

The experiments on an intact isolated heart showed that the studied APC produces no cardiotropic effects, as evidenced by the unchanging values of the myocardial functional activity indicators. Indirectly, ischemia breaks the heart's energy balance, which translates into deteriorating diastolic function, pulse pressure and cardiac output. Introduction of the APC into the isolated heart's perfusate 10 minutes before onset of the total normothermic ischemia slowed down the growth of end-diastolic pressure registered, which reflects the ability of the myocardium to relax, as well as to allow a more complete recovery of the pulse pressure, maximum rate of contraction and relaxation of the left ventricle, with the said growth slower than that registered in the control group $(p<0.05)$ during reperfusion. Thus, the studied APC, when administered to treat ischemic conditions, can reinforce the heart's resistance to insufficiencies of oxygen supply, energy substrates, and increase the stability of the cell membranes of cardiomyocytes under reperfusion [16]

\section{References}

1. Channappanavar R, Perlman S. Pathogenic human coronavirus infections: causes and consequences of cytokine storm and immunopathology. Semin Immunopathol. 2017; 39: 529-39. DOI: 10.1007/s00281-017-0629-x.

2. Su S, et al. Epidemiology, genetic recombination, and pathogenesis of coronaviruses. Trends Microbiol. 2016; 24 (6): 490-502. DOI: 10.1016/j.tim.2016.03.003

3. Gu J, et al. Multiple organ infection and the pathogenesis of SARS J Exp Med. 2005; 202 (3): 415-24. DOI: 10.1084/jem.20050828.

4. Nicholls JM, et al. Lung pathology of fatal severe acute respiratory syndrome. Lancet. 2003; 361 (9371): 1773-8. DOI: 10.1016/ S0140-6736(03)13413-7.

5. Akhmerov A, Marban E. COVID-19 and the Heart. Circ Res. 2020; 126 (10): 1443-55. DOI: 10.1161/circresaha.120.317055.

6. Guo T, Fan Y, Chen M, Wu X, Zhang L, He T, et al. Cardiovascular
The experiments with L-NAME nitric oxide synthase blocker revealed that the APC's cardioprotective action is endotheliumdependent and results from the activation of NO synthase.

Thus, an isolated heart-lungs complex allows simulating development of the pulmonary edema peculiar to COVID-19, which can be used to assess the efficacy of therapeutic and complications prevention agents. Pharmacological action of the active components of APC offers a potential therapeutic way to reduce the magnitude of ischemic damage to the myocardium, preserve energy reserves, restore metabolism and contractile function [17].

\section{CONCLUSIONS}

The study revealed that administration of the APC to an isolated heart-lungs complex significantly reduces the pulmonary edema development rate, with the possible reasons therefor being deterioration of permeability of the blood-air barrier (for perfusate) and the intratracheal pressure's downtrend. The APC offers a cardioprotective effect, helps maintain the effectiveness of myocardial relaxation in diastole and, consequently, reduce the end-diastolic pressure. The use of isolated organs (heart-lungs complex) allows adequate assessment of the parameters of functional activity of vital organs when simulating processes close to the physiological norm, as well pathological conditions, such as, in particular, pulmonary edema and myocardial hypoxia. The method is highly sensitive and enables evaluation of reactivity of the systems exposed to biologically active substances in a wide range of concentrations, as well as identification of the functional change compensation capabilities. implications of fatal outcomes of patients with coronavirus disease 2019 (COVID-19). JAMA Cardiol. 2020; 5 (7): 811-8. DOI: 10.1001/jamacardio.2020.1017.

7. Li J, Benashski SE, Venna VR, McCullough LD. Effects of metformin in experimental stroke. Stroke. 2010; 41: 2645-52.

8. Fung G, Luo H, Qiu Y, Yang D, McManus B. Myocarditis. Circ Res. 2016; 118: 496-514. DOI: 10.1161/CIRCRESAHA.115.306573.

9. Shi S, Qin M, Shen B, Cai Y, Liu T, Yang F, et al. Association of cardiac injury with mortality in hospitalized patients with COVID-19 in Wuhan, China. JAMA Cardiol. 2020; 5 (7): 802-10. DOI: 10.1001/jamacardio.2020.0950.

10. Gundewar S, Calvert JW, Jha S, Toedt_Pingel I, Ji SY, Nunez D, et al. Activation of AMP activated protein kinase by metformin improves left ventricular function and survival in heart failure. Circ Res. 2009; 104: 403-11. 
11. Goransson O, McBride A, Hawley SA, Ross FA, Shpiro N, Foretz M, et al. Mechanism of action of A769662, a valuable tool for activation of AMP activated protein kinase. J Biol Chem. 2007; 282: 32549-60.

12. Barnes K, Ingram JC, Porras OH, Barros LF, Hudson ER, Fryer LG, et al. Activation of GLUT1 by metabolic and osmotic stress: potential involve ment of AMP activated protein kinase (AMPK). J Cell Sci. 2002; 115: 2433-42.

13. Procopio C, Andreozzi F, Laratta E, Cassese A, Beguinot F, Arturi F, et al. Leptin stimulated endothelial nitric oxide synthase via an adenosine 5' monophosphate activated protein kinase/Akt signaling pathway is attenuated by interaction with $\mathrm{C}$ reactive protein. Endocrinology. 2009; 150: 3584-93.

14. Nelson K, Bobba C, Eren E, Spata T, Tadres M, Hayes DJr, et al. Method of isolated ex vivo lung perfusion in a rat model: lessons

\section{Литература}

1. Channappanavar R, Perlman S. Pathogenic human coronavirus infections: causes and consequences of cytokine storm and immunopathology. Semin Immunopathol. 2017; 39: 529-39. DOI: 10.1007/s00281-017-0629-x

2. Su S, et al. Epidemiology, genetic recombination, and pathogenesis of coronaviruses. Trends Microbiol. 2016; 24 (6): 490-502. DOl: 10.1016/j.tim.2016.03.003.

3. Gu J, et al. Multiple organ infection and the pathogenesis of SARS. J Exp Med. 2005; 202 (3): 415-24. DOI: 10.1084/jem.20050828.

4. Nicholls JM, et al. Lung pathology of fatal severe acute respiratory syndrome. Lancet. 2003; 361 (9371): 1773-8. DOI: 10.1016/ S0140-6736(03)13413-7

5. Akhmerov A, Marban E. COVID-19 and the Heart. Circ Res. 2020; 126 (10): 1443-55. DOI: 10.1161/circresaha.120.317055.

6. Guo T, Fan Y, Chen M, Wu X, Zhang L, He T, et al. Cardiovascular implications of fatal outcomes of patients with coronavirus disease 2019 (COVID-19). JAMA Cardiol. 2020; 5 (7): 811-8. DOI: 10.1001/jamacardio.2020.1017

7. Li J, Benashski SE, Venna VR, McCullough LD. Effects of metformin in experimental stroke. Stroke. 2010; 41: 2645-52.

8. Fung G, Luo H, Qu Y, Yang D, McManus B. Myocarditis. Circ Res. 2016; 118: 496-514. DOI: 10.1161/CIRCRESAHA.115.306573.

9. Shi S, Qin M, Shen B, Cai Y, Liu T, Yang F, et al. Association of cardiac injury with mortality in hospitalized patients with COVID-19 in Wuhan, China. JAMA Cardiol. 2020; 5 (7): 802-10. DOI: 10.1001/jamacardio.2020.0950.

10. Gundewar S, Calvert JW, Jha S, Toedt_Pingel I, Ji SY, Nunez D, et al. Activation of AMP activated protein kinase by metformin improves left ventricular function and survival in heart failure. Circ Res. 2009; 104: 403-11. learned from developing a rat EVLP program. J Vis Exp. 2015; 25 (96): 52309. DOI: 10.3791/52309.

15. Chianga $\mathrm{C}$, Pai $\mathrm{H}$, Liu S. Ventilator-induced lung injury (VILI) promotes ischemia/reperfusion lung injury (I/R) and NF-kB antibody attenuates both injuries. Resuscitation. 2008; 79: 147-154.

16. Ishikita A, Matoba T, Ikeda G, Koga JI, Mao Y, Nakano K, et al. Nanoparticle-Mediated Delivery of Mitochondrial Division Inhibitor 1 to the Myocardium Protects the Heart From IschemiaReperfusion Injury Through Inhibition of Mitochondria Outer Membrane Permeabilization: A New Therapeutic Modality for Acute Myocardial Infarction. J Am Heart Assoc. 2016; 5 (7): e003872. DOl: 10.1161/JAHA.116.003872.

17. Kim AS, Miller EJ, Wright TM, Li J, Qi D, Atsina K, et al. A small molecule AMPK activator protects the heart against ischemiareperfusion injury. J Mol Cell Cardiol. 2011; 51: 24-32.

11. Goransson O, McBride A, Hawley SA, Ross FA, Shpiro N, Foretz M, et al. Mechanism of action of A769662, a valuable tool for activation of AMP activated protein kinase. J Biol Chem. 2007; 282: 32549-60.

12. Barnes K, Ingram JC, Porras OH, Barros LF, Hudson ER, Fryer LG, et al. Activation of GLUT1 by metabolic and osmotic stress: potential involve ment of AMP activated protein kinase (AMPK). J Cell Sci. 2002; 115: 2433-42.

13. Procopio C, Andreozzi F, Laratta E, Cassese A, Beguinot F, Arturi F, et al. Leptin stimulated endothelial nitric oxide synthase via an adenosine 5' monophosphate activated protein kinase/Akt signaling pathway is attenuated by interaction with $\mathrm{C}$ reactive protein. Endocrinology. 2009; 150: 3584-93.

14. Nelson K, Bobba C, Eren E, Spata T, Tadres M, Hayes DJr, et al. Method of isolated ex vivo lung perfusion in a rat model: lessons learned from developing a rat EVLP program. J Vis Exp. 2015; 25 (96): 52309. DOI: 10.3791/52309.

15. Chianga $\mathrm{C}$, Pai $\mathrm{H}$, Liu S. Ventilator-induced lung injury (VILI) promotes ischemia/reperfusion lung injury (I/R) and NF-kB antibody attenuates both injuries. Resuscitation. 2008; 79: 147-154.

16. Ishikita A, Matoba T, Ikeda G, Koga JI, Mao Y, Nakano K, et al. Nanoparticle-Mediated Delivery of Mitochondrial Division Inhibitor 1 to the Myocardium Protects the Heart From IschemiaReperfusion Injury Through Inhibition of Mitochondria Outer Membrane Permeabilization: A New Therapeutic Modality for Acute Myocardial Infarction. J Am Heart Assoc. 2016; 5 (7): e003872. DOI: 10.1161/JAHA.116.003872.

17. Kim AS, Miller EJ, Wright TM, Li J, Qi D, Atsina K, et al. A small molecule AMPK activator protects the heart against ischemiareperfusion injury. J Mol Cell Cardiol. 2011; 51: 24-32. 